finition of MOSST's role, the Science Council's position has become even less clear.

It appears that a good deal of soulsearching has been going on behind the scenes. Since a new chairman and a new executive director were appointed-both relatively young men with experience in industry-internal discussions have proceeded about the role and purpose of the Science Council, and a much more publicly visible, popular and practical orientation is envisaged.

The new executive director, John J. Shepherd, who is 46 , was formerly chairman of the board of the hightechnology firm Leigh Instruments of Ottawa. Josef Kates, the chairman of the council, is president of a Torontobased firm of systems analysts. Shepherd believes that council has always tried to reach the public, mostly through its publications, but that the primary audience was other scientists, making its activities too much like "talking to ourselves".

Now the appeal will be broadenedbut with particular attention being paid to communication with industry. This month, the 20 Science Council members, 7 of whom are themselves from industry, will consider a paper that has been prepared to sum- marise the discussions already undertaken and present the views of the council's staff on the future role of the organisation. By early spring, it is hoped that agreement will have been reached on the council's purpose, some goals will have been accepted, and some decisions have been made on how to proceed to meet them.

This approach will contrast with more casual, ad hoc one of the past, and will, it is hoped, prevent endless debate on where the council is going. The kinds of proposals being made to the council in the paper that will be presented are these:

- The council should serve as an early-warning system to signal the need for $R \& D$ in specific areas important to the country. An international conference was sponsored by the council in Toronto in November, for example, on the subject of climatic change. Other possible topics for the future include the problem of fresh water supplies, and cold water problems for northern development.

- The council should define its role in international activities, particularly with respect to other countries' science councils.

- The council should take a view regarding some two or three important issues. Onc is the matter of basic re- search, and a second the question of technological sovereignty, that is, control over the technology the country acquires and the ability to exploit it nationally. Another is the concept of what the Council calls a Conserver Society, implicit in which are recycling and growth limitation. On the question of whether it can be sold to industrialists on the board, $\mathrm{Mr}$ Shepherd says that the Council's approach is that it would involve a lot of industrial opportunity. "It is not a negative, no-growth philosophy but a new opportunity".

One of the questions council members will doubtless ask themselves in considering this is whether they want to take the risk of committing themselves to such a specific policy. John Shepherd hopes they will, feeling that the council has nothing to fear from a re-structured and stronger MOSST. In fact he feels that the stronger MOSST can become, the bigger the public role of the council will be, because independent, though constructive, criticism will be needed all the more. But he sees the council as faced with a challenge in reaching the public: "There is a widespread feeling that $R \& D$ is not paying off. We've got to show very clearly how science is related to jobs".
SEATED in a meeting of the Academic Senate at Berkeley, I was listening to the annual report of the Committee on Academic Freedom. It was one of those occasions when a printed copy is distributed prior to being read from the platform. The report contained the ringing words ". . . in areas of intellectual, scientific, artistic endeavour it is absolutely essential to protect and, indeed, to foster the odd-ball, the deviant, the genius, that blockhead who keeps insisting against all his colleagues that the earth is round and that it circles around the sun." With magnificent courage and perfect hindsight, I thought, we rally round Galileo to thunder defiance at the Inquisitors of 340 years ago, whose muddy vesture of decay keeps them from hearing us.

But what about the genius who insists that the Earth is flat? Especially the one who teaches this to university students. Let us remember that for every Galileo there were hundreds of odd-balls who kept proclaiming that the Moon was made of green cheese, or that the fault, dear Brutus, was not in ourselves, but in our stars, that we are underlings! Do we fight courageously, implacably, in the name of academic freedom, or the wider cause of freedom of speech and the press, to protect and foster soothsayers and alchemists? Should the Department of Astronomy appoint a Professor of

\section{Equal time for nonsense}

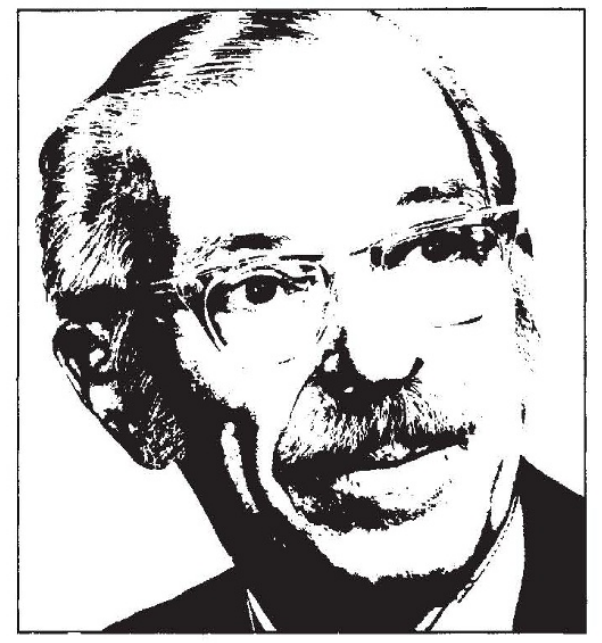

THOMAS H. JUKES

Astrology because, as the resolution went on to say, "the intellectual deviant is one of our most precious resources?"

Don't overlook the fact that opponents of the scientific "establishment" are well aware of public sympathy for the underdog and of how easy it is to get equal time in the media. Some months ago I was asked to talk on television about nutrition. When I arrived at the studio, I found that the programme was to be spiced up by having me debate a "health food" salesman who had copped the spot by demanding "equal time". He regaled the audience with an account of the difference between natural and synthetic ascorbic acids. The natural variety, said he, bent a laser beam of light to the right, but synthetic ascorbic acid turned it to the left. Of course, I told the audience that it ain't so, but it was another case of disagreement between experts, and the television station loved it. Nothing like a oneagainst-one controversy to please listeners and boost the ratings.

So ended my effort on this occasion to bring nutrition from the ivory tower to the public ear. I departed, still dedicated to free speech, but well aware that those who own and control television stations and newspapers decide who gets it. And, right now, the odd-balls are doing very nicely. Acupuncture today, moxibustion tomorrow. Horoscopes were cast in a Nature article in April last year. We are approaching a state of affairs in which reactionary deviants who insist that the Earth circles round the Sun may indeed need protection.

Perhaps the Committee on Academic Freedom was right without really knowing why. 